\title{
From evidence based medicine to mechanism based medicine. Reviewing the role of pharmacogenetics
}

\author{
Bob Wilffert · Jesse Swen · Hans Mulder • Daan Touw • \\ Anke-Hilse Maitland-Van der Zee • Vera Deneer • \\ KNMP working group Pharmacogenetics
}

Received: 16 July 2010/Accepted: 4 October 2010/Published online: 4 November 2010

(c) The Author(s) 2010. This article is published with open access at Springerlink.com

\begin{abstract}
Aim of the review The translation of evidence based medicine to a specific patient presents a considerable challenge. We present by means of the examples nortriptyline, tramadol, clopidogrel, coumarins, abacavir and antipsychotics the discrepancy between available pharmacogenetic information and its implementation in daily clinical practice. Method Literature review. Results A mechanism based approach may be helpful to personalize
\end{abstract}

B. Wilffert $(\square)$

Department of Quality and Patientsafety, Zorggroep

Noorderbreedte, P.O. Box 888, 8901 BR Leeuwarden,

The Netherlands

e-mail: B.Wilffert@ZNB.NL

\section{J. Swen}

Department of Clinical Pharmacy and Toxicology, Leiden

University Medical Center, P.O. Box 9600, 2300 RC Leiden,

The Netherlands

H. Mulder

Department of Clinical Pharmacy, Wilhelmina Hospital Assen,

Assen, The Netherlands

D. Touw

Apotheek Haagse Ziekenhuizen, P.O. Box 43100, 2504 AC Den

Haag, The Netherlands

\section{A.-H. Maitland-Van der Zee}

Department of Pharmacoepidemiology and Pharmacotherapy, Utrecht Institute for Pharmaceutical Sciences (UIPS), University of Utrecht, Utrecht, The Netherlands

\section{Deneer}

Department of Clinical Pharmacy, St. Antonius Hospital,

P.O. Box 2500, 3430 EM Nieuwegein, The Netherlands

KNMP working group Pharmacogenetics

KNMP/GIC, P.O. Box 304640, 2500 GL The Hague,

The Netherlands medicine for the individual patient to which pharmacogenetics may contribute significantly. The lack of consistency in what we accept in bioequivalence and in pharmacogenetics of drug metabolising enzymes is discussed and illustrated with the example of nortriptyline. The impact of pharmacogenetics on examples like tramadol, clopidogrel, coumarins and abacavir is described. Also the present status of the polymorphisms of 5-HT2A and C receptors in antipsychotic-induced weight gain is presented as a pharmacodynamic example with until now a greater distance to clinical implementation. Conclusion The contribution of pharmacogenetics to tailor-made pharmacotherapy, which especially might be of value for patients deviating from the average, has not yet reached the position it seems to deserve.

Keywords Drug metabolising enzymes - Mechanism based medicine - Pharmacodynamics - Pharmacogenetics . Pharmacokinetics

\section{Introduction}

Evidence based medicine applies guidelines developed on the basis of consensus from randomized clinical trials (RCTs). These RCTs are performed in carefully selected patient-populations studied under strongly regulated conditions. It often is a challenge to translate the results of the RCTs to a specific patient in the real world [1]. In RCTs often (young) people having one specific disease are selected. In daily clinical practice a significant part of the patients consists of elderly patients often having multiple morbidities. For the majority of these patients still no evidenced based medication is available. Therefore in these situations there seems to be a need for a mechanism based 
approach towards medicine personalized for the individual patient. In mechanism based medicine it is already common practice to adjust drug dose to age, liver and renal function. Pharmacogenetics-the study of variations in DNA sequence as related to drug response-is trying to obtain its position among these factors [2]. Nevertheless we experience a lack of enthusiasm in the implementation of pharmacogenetics, especially when compared with for instance adaptation of drug dosing to liver or renal function or bodyweight for children.

\section{Aim of the review}

To review the evidence for the usefulness of pharmacogenetic information in relation to clinical implementation of this pharmacogenetic information.

\section{Method}

We summarized the available information in the literature for the pharmacogenetic information for nortriptyline (CYP2D6), tramadol(CYP2D6), clopidogrel(CYP2C19), coumarins(CYP2C9 and VKORC1), abacavir(HLA$\mathrm{B} * 5701$ ) and the relation between polymorphism of 5-HT2A and C-receptors and antipsychotic induced weight gain as typical examples and compared this with the clinical implementation of these pharmacogenetic parameters. This is put into the perspective of accepted differences in bioequivalence.

\section{Results/Discussion}

In evidence based medicine the Guideline on the investigation of bioequivalence (CPMP/EWP/QWP/1401/98 Rev.1/corr) is applied to assess whether generic medicines are bioequivalent with the already marketed reference drugs. In this guideline, bioequivalence is accepted if the 90\% confidence interval of the ratio of the Area Under the Curve (AUC) of the generic drug and the AUC of the reference drug lies within $80.00-125.00 \%$. For highly variable drug products we accept extreme values up to $69.84-143.19 \%$ if this extent of variation is considered clinically irrelevant as long as the geometric mean ratio lies within $80.00-125.00 \%$. With this in mind it is remarkable that regulatory authorities do not require the application of pharmacogenetics during the process of drug prescribing and dispensing in the numerous examples of drugs for which the AUC appears to deviate much stronger on a pharmacogenetic basis, as accepted in the above mentioned guideline. Here we present such an example, discuss barriers for the clinical implementation of pharmacogenetics and plea for a more mechanism based approach to medicine.

A classic example of pharmacogenetics is the variability in effect of the antidepressant nortriptyline due to different genotypes. The plasma levels of nortriptyline may vary almost tenfold depending on the number of functional CYP2D6 allelles. Still we accept to use the same dose in ultrarapid metabolisers for CYP2D6 (5-10\% of the Caucasian population) and for intermediate and poor metabolisers for CYP2D6 (15-25\% of the Caucasian population) as for the so called extensive metabolisers [3, 4]. In other words the same tablet of nortriptyline administered to a poor or intermediate metaboliser is not bioequivalent with the tablet administered to an extensive metaboliser. Therefore, a one size fits all starting dose for nortriptyline can not be considered an example of evidence based medicine.

A second example for which from the perspective of evidence based medicine it is hard to understand that pharmacogenetics are not applied is tramadol, a $\mu$-receptor agonist which also inhibits reuptake of serotonin and noradrenaline [5]. This drug demonstrated efficacy in several neuropathic pain conditions. However tramadol is a 50:50 mixture of $(+) \mathrm{R}, \mathrm{R}$ - and $(-) \mathrm{S}, \mathrm{S}$-enantiomer which are Odemethylated by CYP2D6 to the so called $\mathrm{M}_{1}$ - metabolites [6]. (+)- and (-)-Tramadol as well as (+)- and (-) - $\mathrm{M}_{1}$ strongly differ in affinity for the $\mu$-receptor, the noradrenaline- and 5-HT-uptake [7]. This results in a different pharmacological profile of tramadol for the different CYP2D6 phenotypes. In ultrarapid and extensive metabolisers tramadol has much more $\mu$-receptor agonist effect than in poor metabolisers [8]. In the latter a more pronounced noradrenaline- and 5-HT-uptake mediated effect will be observed. The evidence for the successful treatment of neuropathic pain with tramadol is based predominantly on extensive metabolisers, because this is the largest phenotype group. However, in these patients we deal with another active principle for tramadol than in patients with variant genotypes for CYP2D6 where the effect will be more dominated by the $\mu$-receptor agonistic (ultrarapid metabolisers) or the noradrenaline- and the 5-HT-uptake inhibiting effect (poor metabolisers). Therefore in the Netherlands it is advised to select an alternative for tramadol in poor, ultrarapid and intermediate metabolisers for CYP2D6 [3].

A third example is the antiplatelet drug clopidogrel. In evidence based medicine one often develops pharmacotherapeutic strategies based on post hoc or subgroup analysis of large randomized clinical trials. However, before applying pharmacogenetic knowledge from post hoc analysis, in daily clinical practice one calls for additional randomized studies. Prasugrel, another antiplatelet drug, was compared to clopidogrel in over 13,000 patients with 
an acute coronary syndrome undergoing a percutaneous coronary intervention (PCI) in the TRITON-TIMI 38 study [9]. In a post hoc analysis in approximately 3,500 patients with ST segment elevation myocardial infarction (STEMI), prasugrel appeared to be more effective than clopidogrel in preventing the occurrence of cardiovascular ischemic events without an increased risk of developing bleedings [10]. The NICE appraisal recommends prasugrel as an option when immediate PCI for STEMI is necessary. In another post hoc analysis including clopidogrel treated patients of the TRITON-TIMI 38 study, the influence of genetic variants of CYP2C19 on the occurrence of cardiovascular ischemic events was studied. Clopidogrel is a prodrug which requires biotransformation to the active metabolite by the polymorphic CYP2C19. Carriage of genetic variants encoding for non functional CYP2C19 enzyme was associated with an increased risk of stent thrombosis and the combined endpoint of cardiovascular death, myocardial infarction or stroke [11]. This association was also observed in other studies and recently even resulted in a boxed warning by the FDA about the reduced effectiveness of clopidogrel in homozygous carriers of a CYP2C19 non functional allele. Nevertheless experts do not recommend routine genetic testing yet since there is no or limited information regarding the predictive value of genetic testing and the effect of a genotype guided treatment strategy on clinical outcome based on the results of randomized studies with sufficient power [12].

Besides genetically determined differences in pharmacokinetics, the variability in drug response can also be attributed to genetic variability in factors influencing drug action, for example, the drug receptor level (pharmacodynamics) [13]. As an example, in psychiatric pharmacotherapy at least two subtypes of the serotonin (5-HT) receptor have shown to be important: the 5-HT2A and the 5-HT2C receptor [14-16]. Polymorphisms in the HTR2C gene coding for the 5-HT2C receptor are of interest because of the association between HTR2C polymorphisms and the response of antipsychotic drugs [17] but also because of the association between HTR2C polymorphisms and antipsychotic-induced weight gain [16]. The translation to the corresponding clinical phenotype of pharmacodynamic polymorphisms like HTR2C is more complex than the translation of pharmacokinetic polymorphisms like CYP2D6. The consequences of pharmacokinetic polymorphisms can quite easily be measured with standard pharmacokinetic parameters (surrogate endpoints) like the steady state concentration, elimination half-live and the area under the curve (AUC) of administered drugs. The consequences of pharmacodynamic polymorphisms are more difficult to measure [13]. The pharmacodynamic polymorphisms have to be translated to a clinical phenotype based upon the expected function of the gene where the polymorphism is located. One of the limitations of this approach is that the clinical phenotype as a result of gene expression is not well known for many drug targeting receptors. The gene coding for the 5 -HT2c receptor is an example of a drug targeting receptor with a relatively unknown phenotype. One of the suggested clinical phenotypes of the HTR2C gene is a function in regulation of food intake and weight gain but results are conflicting [18-25]. This pharmacodynamic polymorphism is one example of many others. However, the difficulties as described above impede implementation of genotyping of pharmacodynamic in contrast to pharmacokinetic polymorphisms in daily clinical practice at this moment.

Especially pharmacokinetic examples illustrate the discrepancy between the generally accepted limits for bioequivalence applied by the regulatory authorities and their position taken in pharmacogenetics. However, there are examples where the regulatory authorities took a clear standpoint with respect to the application of pharmacogenetics. Because of the increased risk of hypersensitivity reactions, on March 10, 2008 the CBG-MEB has revised the Summary of Product Characteristics of abacavir to include the advise to screen for HLA-B*5701 prior to treatment initiation and that abacavir should not be used in carriers of this polymorphism, unless there is no therapeutic alternative. An overview of drugs with a pharmacogenomic labelling from EMA and FDA for which genotyping is recommended or required can be found for instance in the paper of Becquemont [26]. Also the draft Guideline on the use of pharmacogenetic methodologies in the pharmacokinetic evaluation of medicinal products from the EMA (EMA/CHMP/37646/2009) reflects a clear role for pharmacogenetics in the evaluation of efficacy and safety of drugs as considered by the regulatory authority.

Where are we standing now? The current use of genotyping is mostly limited to diagnostics with a focus on adverse drug events in individual patients. Prevention of toxicity and treatment optimization through prospective screening is still far from being common practice. However, there are major developments in the field. Multiple relatively rare adverse drug events such as flucloxacillineinduced liver injury [27], Stevens-Johnson syndrome induced by carbamazepine [28], and the hypersensitivity reaction to abacavir [29] have all been associated with specific HLA-B genotypes. For the latter, a prospective study showed that the hypersensitivity reaction can be prevented by screening patients prior to treatment with abacavir [29].

Furthermore, pharmacogenetic research has progressed from searching for associations between individual SNPs and treatment outcome, through combinations of multiple SNPs affecting pharmacokinetics and pharmacodynamics, to the use of pharmacogenetic models including SNPs as 
well as more traditional clinical variables such as age, renal function and bodyweight. The inclusion of these traditional clinical variables is essential since individuals belonging to the same pharmacogenetic class still may vary about 10fold in metabolic ratio, demonstrating that pharmacogenetics can not explain all interindividual differences, but is only one additional component [30].

For the coumarins much clinical evidence is present (especially from observational research) for the added value of knowledge of the genotype of CYP2C9 and VKORC1 for safe application which is not reflected yet in clinical application (see e.g. [31, 32]). The progress from individual SNPs to pharmacogenetic models is well exemplified by the coumarin warfarin. This drug is metabolised by the polymorphic enzyme CYP2C9. The CYP2C9 genotype alone explained 5-18\% of the variation in required warfarin dose [33]. It was already reported that genetic variability in VKORC1, a gene coding for vitamine $\mathrm{K}$ epoxide reductase, a key enzyme in the vitamine $\mathrm{K}$ cycle, could explain
$15-37 \%$ of the variation in required warfarin dose [34-37]. Recently models including genetic variants of VKORC1, CYP2C9 and clinical factors such as age, sex, height and bodyweight have been reported to explain up to $50 \%$ of variation in required warfarin dose [38].

We know that genotyping can give useful information for the prescription of certain drugs which could lead to a balanced use of genotyping. It should be emphasized that the role of pharmacogenetics may be more compelling if at the start of therapy with a new drug a quick finding of the right dose is of importance or in cases where hypersensitivity reactions are involved. If there is chosen for the approach of starting with an almost universally tolerated dose, which then is gradually increased until the desired effects are achieved or the onset of unacceptable side effects, the advantage of the application of pharmacogenetics may be less pronounced although even then a more appropriate, tailor made starting dose may be selected. Also Therapeutic Drug Monitoring could be improved by

Table 1 Examples of therapeutic (dose) recommendations

\begin{tabular}{|c|c|c|c|c|}
\hline Drug (Enzyme) & $\begin{array}{l}\text { Genotype or } \\
\text { phenotype }\end{array}$ & $\begin{array}{l}\text { Gene-drug } \\
\text { interaction }\end{array}$ & Therapeutic (dose) recommendation & References \\
\hline \multirow[t]{3}{*}{ Tramadol (CYP2D6) } & $\mathrm{PM}$ & Yes & $\begin{array}{l}\text { Select alternative drug (e.g. acetaminophen, NSAID, morphine NOT } \\
\text { oxycodone or codeine) or be alert to symptoms of insufficient pain } \\
\text { relief }\end{array}$ & [43-48] \\
\hline & $\mathrm{IM}$ & Yes & $\begin{array}{l}\text { Select alternative drug (e.g. acetaminophen, NSAID, morphine NOT } \\
\text { oxycodone or codeine) or be alert to symptoms of insufficient pain } \\
\text { relief }\end{array}$ & {$[43,44,49]$} \\
\hline & $\mathrm{UM}$ & Yes & $\begin{array}{l}\text { Select alternative drug (e.g. acetaminophen, NSAID, morphine NOT } \\
\text { oxycodone or codeine) or be alert to ADE (e.g. nausea, vomiting, } \\
\text { constipation, respiratory depression, confusion, urinary retention) }\end{array}$ & {$[50]$} \\
\hline \multirow[t]{5}{*}{$\begin{array}{l}\text { Phenytoin } \\
\text { (CYP2C9) }\end{array}$} & $* 1 / * 2$ & Yes & $\begin{array}{l}\text { Standard loading dose. Reduce maintenance dose by } 25 \% \text {. Evaluate } \\
\text { response and serum concentration after } 7-10 \text { days. Be alert to ADE } \\
\text { (e.g. ataxia, nystagmus, dysarthria, sedation) }\end{array}$ & {$[51-57]$} \\
\hline & $* 1 / * 3$ & Yes & $\begin{array}{l}\text { Standard loading dose. Reduce maintenance dose by } 25 \% \text {. Evaluate } \\
\text { response and serum concentration after } 7-10 \text { days. Be alert to ADE } \\
\text { (e.g. ataxia, nystagmus, dysarthria, sedation) }\end{array}$ & {$[51-55,58-65]$} \\
\hline & $* 2 / * 2$ & Yes & $\begin{array}{l}\text { Standard loading dose. Reduce maintenance dose by } 50 \% \text {. Evaluate } \\
\text { response and serum concentration after } 7-10 \text { days. Be alert to ADE } \\
\text { (e.g. ataxia, nystagmus, dysarthria, sedation) }\end{array}$ & {$[51-54,56,57]$} \\
\hline & $* 2 / * 3$ & Yes & $\begin{array}{l}\text { Standard loading dose. Reduce maintenance dose by } 50 \% \text {. Evaluate } \\
\text { response and serum concentration after } 7-10 \text { days. Be alert to ADE } \\
\text { (e.g. ataxia, nystagmus, dysarthria, sedation) }\end{array}$ & {$[52,57]$} \\
\hline & $* 3 / * 3$ & Yes & $\begin{array}{l}\text { Standard loading dose. Reduce maintenance dose by } 50 \% \text {. Evaluate } \\
\text { response and serum concentration after } 7-10 \text { days. Be alert to ADE } \\
\text { (e.g. ataxia, nystagmus, dysarthria, sedation) }\end{array}$ & {$[51,54-56,60,66-69]$} \\
\hline \multirow{3}{*}{$\begin{array}{l}\text { Citalopram/ } \\
\text { Escitalopram } \\
\text { (CYP2C19) }\end{array}$} & $\mathrm{PM}$ & Yes & No & {$[70-76]$} \\
\hline & $\mathrm{IM}$ & Yes & No & {$[72,73,75-77]$} \\
\hline & UM & Yes & $\begin{array}{l}\text { Monitor plasma concentration and titrate dose to max. } 150 \% \text { in } \\
\text { response to efficacy and ADE or select alternative drug (e.g. } \\
\text { fluoxetine, paroxetine) }\end{array}$ & {$[73,78]$} \\
\hline
\end{tabular}

For a complete list of therapeutic (dose) recommendations see ref. [3] 
including genetic information. Pharmacogenetics may increase benefit and reduce harm in people whose drug response is not 'average' [39]. However, clinical implementation remains limited [40]. Maybe the cause of the slow integration of pharmacogenetic testing in clinical practice to improve dosing and minimize safety risks is the urge for appropriate education of prescribing physicians, ethics committees, and investigators on the use and interpretation of the pharmacogenetic information provided in the drug label [41]. The above mentioned example of the coumarins seems to indicate that clinical evidence does not suffice to implement pharmacogenetics in daily practice, but first mega-trials have to be performed [31]. The availability of the genotype information and the connected turn around time for the lab are also often referred to, but are solvable problems. The pronounced discussion on costeffectiveness in the field of genotyping contrasts with the implementation of specific requirements for e.g. drug dosing in children or therapeutic drug monitoring. Furthermore it is highly likely that this cost discussion will fade away in the not so distant future since the costs of genotyping are dropping every day [42]. Between 10 and 20 years from now we will probably all have our DNA sequence available in medical records. By then genotyping costs will no longer be important, however it will be even more important to have guidelines on how to clinically make use of all this information.

To support the implementation of pharmacogenetics, the Royal Dutch Association for the Advancement of Pharmacy (KNMP) installed a multidisciplinary working group with the objective to develop pharmacogenetics-based therapeutic (dose) recommendations based upon a systematic review of the literature and to assist prescribers by integrating the recommendations into computerized systems for prescribing and automated medication surveillance [3]. These data are electronically available to all pharmacists in the Netherlands. Examples of these are provided in Table 1. For each genotype/phenotype-drug combination it is clearly stated whether there is an interaction or not with the polymorphism specified and which action is required. It would contribute to medication safety if in those cases were genotyping results in adaptation of pharmacotherapy, genotyping would indeed be performed.

\section{Conclusion}

In conclusion, evidence based medicine still aims at an average patient from a carefully selected patient population, but does not do justice to the individual characteristics of patients. If one adds knowledge of the mechanisms of pathology, knowledge of mechanism of action of drugs, both pharmacodynamically and pharmacokinetically, as well as the knowledge of the individual patient including his pharmacogenetic characteristics if relevant for the pharmacotherapy considered, the result will be a tailormade pharmacotherapy. This might be considered a commodity in the current era so strongly characterised by an emphasis on attention for medication safety.

Funding None.

Conflicts of interest The division of Pharmacoepidemiology \& Clinical Pharmacology employing author Anke-Hilse Maitland-van der Zee, has received unrestricted funding for pharmacoepidemiological research from GlaxoSmithKline, Novo Nordisk, the privatepublic funded Top Institute Pharma (http://www.tipharma.nl, includes co-funding from universities, government, and industry), the Dutch Medicines Evaluation Board, and the Dutch Ministry of Health.

Open Access This article is distributed under the terms of the Creative Commons Attribution Noncommercial License which permits any noncommercial use, distribution, and reproduction in any medium, provided the original author(s) and source are credited.

\section{References}

1. de Graaf L. Force doctors to a joined consultation. Pharm Weekbl. 2009;45:8-11.

2. Huang SM, Temple R. Is this the drug or dose for you? Impact and consideration of ethnic factors in global drug development, regulatory review, and clinical practice. Clin Pharmacol Ther. 2008;84(3):287-94.

3. Swen JJ, Wilting I, de Goede AL, Grandia L, Mulder H, Touw DJ, et al. Pharmacogenetics: from bench to byte. Clin Pharmacol Ther. 2008;83(5):781-7.

4. Weinshilboum R. Inheritance and drug response. N Engl J Med. 2003;348(6):529-37.

5. O'Connor AB, Dworkin RH. Treatment of neuropathic pain: an overview of recent guidelines. Am J Med. 2009;122(10 Suppl): S22-32.

6. Halling J, Weihe P, Brosen K. CYP2D6 polymorphism in relation to tramadol metabolism: a study of faroese patients. Ther Drug Monit. 2008;30(3):271-5.

7. Frink MC, Hennies HH, Englberger W, Haurand M, Wilffert B. Influence of tramadol on neurotransmitter systems of the rat brain. Arzneimittelforschung. 1996;46(11):1029-36.

8. Kirchheiner J, Keulen JT, Bauer S, Roots I, Brockmoller J. Effects of the CYP2D6 gene duplication on the pharmacokinetics and pharmacodynamics of tramadol. J Clin Psychopharmacol. 2008;28(1):78-83.

9. Wiviott SD, Braunwald E, McCabe CH, Montalescot G, Ruzyllo $\mathrm{W}$, Gottlieb S, et al. Prasugrel versus clopidogrel in patients with acute coronary syndromes. N Engl J Med. 2007;357(20): 2001-15.

10. Montalescot G, Wiviott SD, Braunwald E, Murphy SA, Gibson $\mathrm{CM}, \mathrm{McCabe} \mathrm{CH}$, et al. Prasugrel compared with clopidogrel in patients undergoing percutaneous coronary intervention for STelevation myocardial infarction (TRITON-TIMI 38): double-blind, randomised controlled trial. Lancet. 2009;373(9665):723-31.

11. Mega JL, Close SL, Wiviott SD, Shen L, Hockett RD, Brandt JT, et al. Cytochrome p-450 polymorphisms and response to clopidogrel. N Engl J Med. 2009;360(4):354-62.

12. Holmes DR, Jr., Dehmer GJ, Kaul S, Leifer D, O'Gara PT, Stein $\mathrm{CM}$. ACCF/AHA clopidogrel clinical alert: approaches to the FDA 
"Boxed Warning". A report of the American College of Cardiology Foundation Task force on clinical expert consensus documents and the American Heart Association. Circulation 2010.

13. Roden DM, Altman RB, Benowitz NL, Flockhart DA, Giacomini KM, Johnson JA, et al. Pharmacogenomics: challenges and opportunities. Ann Intern Med. 2006;145(10):749-57.

14. Lieberman JA, Mailman RB, Duncan G, Sikich L, Chakos M, Nichols DE, et al. Serotonergic basis of antipsychotic drug effects in schizophrenia. Biol Psychiatry. 1998;44(11):1099-117.

15. Reynolds GP, Templeman LA, Zhang ZJ. The role of 5-HT2C receptor polymorphisms in the pharmacogenetics of antipsychotic drug treatment. Prog Neuropsychopharmacol Biol Psychiatry. 2005;29(6):1021-8.

16. Reynolds GP, Hill MJ, Kirk SL. The 5-HT2C receptor and antipsychoticinduced weight gain-mechanisms and genetics. J Psychopharmacol. 2006;20(4 Suppl):15-8.

17. Arranz MJ, Munro J, Birkett J, Bolonna A, Mancama D, Sodhi $\mathrm{M}$, et al. Pharmacogenetic prediction of clozapine response. Lancet. 2000;355(9215):1615-6.

18. De Luca V, Mueller DJ, de BA, Kennedy JL. Association of the HTR2C gene and antipsychotic induced weight gain: a metaanalysis. Int J Neuropsychopharmacol. 2007;10(5):697-704.

19. Mulder H, Franke B, van der van der-Beek AA, Arends J, Wilmink FW, Scheffer H, et al. The association between HTR2C gene polymorphisms and the metabolic syndrome in patients with schizophrenia. J Clin Psychopharmacol. 2007;27(4):338-43.

20. Mulder H, Franke B, van der Beek AA, Arends J, Wilmink FW, Egberts AC, et al. The association between HTR2C polymorphisms and obesity in psychiatric patients using antipsychotics: a cross-sectional study. Pharmacogenomics J. 2007;7(5):318-24.

21. Mulder H, Cohen D, Scheffer H, Gispen-de WC, Arends J, Wilmink FW, et al. HTR2C gene polymorphisms and the metabolic syndrome in patients with schizophrenia: a replication study. J Clin Psychopharmacol. 2009;29(1):16-20.

22. Park YM, Cho JH, Kang SG, Choi JE, Lee SH, Kim L, et al. Lack of association between the $-759 \mathrm{C} / \mathrm{T}$ polymorphism of the 5-HT2C receptor gene and olanzapine-induced weight gain among Korean schizophrenic patients. J Clin Pharm Ther. 2008;33(1):55-60.

23. Reynolds GP, Zhang Z, Zhang X. Polymorphism of the promoter region of the serotonin 5-HT(2C) receptor gene and clozapineinduced weight gain. Am J Psychiatry. 2003;160(4):677-9.

24. Templeman LA, Reynolds GP, Arranz B, San L. Polymorphisms of the 5-HT2C receptor and leptin genes are associated with antipsychotic drug-induced weight gain in Caucasian subjects with a first-episode psychosis. Pharmacogenet Genomics. 2005; 15(4): 195-200.

25. Theisen FM, Hinney A, Bromel T, Heinzel-Gutenbrunner M, Martin M, Krieg JC, et al. Lack of association between the -759C/ $\mathrm{T}$ polymorphism of the 5-HT2C receptor gene and clozapineinduced weight gain among German schizophrenic individuals. Psychiatr Genet. 2004;14(3):139-42.

26. Becquemont L. Pharmacogenomics of adverse drug reactions: practical applications and perspectives. Pharmacogenomics. 2009;10(6):961-9.

27. Daly AK, Donaldson PT, Bhatnagar P, Shen Y, Pe'er I, Floratos A, et al. HLA-B*5701 genotype is a major determinant of druginduced liver injury due to flucloxacillin. Nat Genet. 2009;41(7): 816-9.

28. Chung WH, Hung SI, Hong HS, Hsih MS, Yang LC, Ho HC, et al. Medical genetics: a marker for Stevens-Johnson syndrome. Nature. 2004;428(6982):486.

29. Mallal S, Phillips E, Carosi G, Molina JM, Workman C, Tomazic J, et al. HLA-B*5701 screening for hypersensitivity to abacavir. N Engl J Med. 2008;358(6):568-79.

30. Meyer UA. Pharmacogenetics-five decades of therapeutic lessons from genetic diversity. Nat Rev Genet. 2004;5(9):669-76.
31. van Schie RM, Cascorbi I, Maitland-van der Zee AH. Conference scene: pharmacogenomics at the second PharmSciFair 2009: adverse drug reactions and clinical implementation. Pharmacogenomics. 2009;10(9):1389-91.

32. Wilms EB, Veldkamp RF, van ME, Touw DJ. Partial resistance to acenocoumarol and phenprocoumon caused by enzyme polymorphism. Ned Tijdschr Geneeskd. 2006;150(38):2095-8.

33. Tan GM, Wu E, Lam YY, Yan BP. Role of warfarin pharmacogenetic testing in clinical practice. Pharmacogenomics. 2010; 11(3):439-48.

34. D'Andrea G, D'Ambrosio RL, Di PP, Chetta M, Santacroce R, Brancaccio $\mathrm{V}$, et al. A polymorphism in the VKORC1 gene is associated with an interindividual variability in the dose-anticoagulant effect of warfarin. Blood. 2005;105(2):645-9.

35. Li T, Chang CY, Jin DY, Lin PJ, Khvorova A, Stafford DW. Identification of the gene for vitamin $\mathrm{K}$ epoxide reductase. Nature. 2004;427(6974):541-4.

36. Rieder MJ, Reiner AP, Gage BF, Nickerson DA, Eby CS, McLeod HL, et al. Effect of VKORC1 haplotypes on transcriptional regulation and warfarin dose. N Engl J Med. 2005;352(22):2285-93.

37. Rost S, Fregin A, Ivaskevicius V, Conzelmann E, Hortnagel K, Pelz HJ, et al. Mutations in VKORC1 cause warfarin resistance and multiple coagulation factor deficiency type 2. Nature. 2004;427(6974):537-41.

38. Klein TE, Altman RB, Eriksson N, Gage BF, Kimmel SE, Lee MT, et al. Estimation of the warfarin dose with clinical and pharmacogenetic data. N Engl J Med. 2009;360(8):753-64.

39. Woodcock J, Lesko LJ. Pharmacogenetics-tailoring treatment for the outliers. N Engl J Med. 2009;360(8):811-3.

40. Swen JJ, Huizinga TW, Gelderblom H, de Vries EG, Assendelft WJ, Kirchheiner J, et al. Translating pharmacogenomics: challenges on the road to the clinic. PLoS Med. 2007;4(8):e209.

41. Williams JA, Andersson T, Andersson TB, Blanchard R, Behm MO, Cohen N, et al. PhRMA white paper on ADME pharmacogenomics. J Clin Pharmacol. 2008;48(7):849-89.

42. Check HE. Genome sequencing: the third generation. Nature. 2009;457(7231):768-9.

43. Abdel-Rahman SM, Leeder JS, Wilson JT, Gaedigk A, Gotschall RR, Medve R, et al. Concordance between tramadol and dextromethorphan parent/metabolite ratios: the influence of CYP2D6 and non-CYP2D6 pathways on biotransformation. J Clin Pharmacol. 2002;42(1):24-9.

44. Borlak J, Hermann R, Erb K, Thum T. A rapid and simple CYP2D6 genotyping assay-case study with the analgetic tramadol. Metabolism. 2003;52(11):1439-43.

45. Enggaard TP, Poulsen L, rendt-Nielsen L, Brosen K, Ossig J, Sindrup SH. The analgesic effect of tramadol after intravenous injection in healthy volunteers in relation to CYP2D6. Anesth Analg. 2006;102(1):146-50.

46. Paar WD, Poche S, Gerloff J, Dengler HJ. Polymorphic CYP2D6 mediates $\mathrm{O}$-demethylation of the opioid analgesic tramadol. Eur J Clin Pharmacol. 1997;53(3-4):235-9.

47. Poulsen L, rendt-Nielsen L, Brosen K, Sindrup SH. The hypoalgesic effect of tramadol in relation to CYP2D6. Clin Pharmacol Ther. 1996;60(6):636-44.

48. Stamer UM, Lehnen K, Hothker F, Bayerer B, Wolf S, Hoeft A, et al. Impact of CYP2D6 genotype on postoperative tramadol analgesia. Pain. 2003;105(1-2):231-8.

49. Gan SH, Ismail R, Wan Adnan WA, Wan Z. Correlation of tramadol pharmacokinetics and CYP2D6*10 genotype in Malaysian subjects. J Pharm Biomed Anal. 2002;30(2):189-95.

50. Gleason PP, Frye RF, O'Toole T. Debilitating reaction following the initial dose of tramadol. Ann Pharmacother. 1997;31(10): $1150-2$.

51. Aynacioglu AS, Brockmoller J, Bauer S, Sachse C, Guzelbey P, Ongen Z, et al. Frequency of cytochrome P450 CYP2C9 variants 
in a Turkish population and functional relevance for phenytoin. Br J Clin Pharmacol. 1999;48(3):409-15.

52. Caraco Y, Muszkat M, Wood AJ. Phenytoin metabolic ratio: a putative marker of CYP2C9 activity in vivo. Pharmacogenetics. 2001;11(7):587-96.

53. Hennessy S, Leonard CE, Freeman CP, Metlay JP, Chu X, Strom BL, et al. CYP2C9, CYP2C19, and ABCB1 genotype and hospitalization for phenytoin toxicity. J Clin Pharmacol. 2009; 49(12):1483-7.

54. Kerb R, Aynacioglu AS, Brockmoller J, Schlagenhaufer R, Bauer $\mathrm{S}$, Szekeres T, et al. The predictive value of MDR1, CYP2C9, and CYP2C19 polymorphisms for phenytoin plasma levels. Pharmacogenomics J. 2001;1(3):204-10.

55. Rosemary J, Surendiran A, Rajan S, Shashindran CH, Adithan C. Influence of the CYP2C9 AND CYP2C19 polymorphisms on phenytoin hydroxylation in healthy individuals from south India. Indian J Med Res. 2006;123(5):665-70.

56. Tate SK, Depondt C, Sisodiya SM, Cavalleri GL, Schorge S, Soranzo N, et al. Genetic predictors of the maximum doses patients receive during clinical use of the anti-epileptic drugs carbamazepine and phenytoin. Proc Natl Acad Sci U S A. 2005;102(15):5507-12.

57. van der Weide WJ, Steijns LS, van Weelden MJ, de HK. The effect of genetic polymorphism of cytochrome P450 CYP2C9 on phenytoin dose requirement. Pharmacogenetics. 2001;11(4):287-91.

58. Hashimoto Y, Otsuki Y, Odani A, Takano M, Hattori H, Furusho $\mathrm{K}$, et al. Effect of CYP2C polymorphisms on the pharmacokinetics of phenytoin in Japanese patients with epilepsy. Biol Pharm Bull. 1996;19(8):1103-5.

59. Hung CC, Lin CJ, Chen CC, Chang CJ, Liou HH. Dosage recommendation of phenytoin for patients with epilepsy with different CYP2C9/CYP2C19 polymorphisms. Ther Drug Monit. 2004;26(5):534-40.

60. Lee SY, Lee ST, Kim JW. Contributions of CYP2C9/CYP2C19 genotypes and drug interaction to the phenytoin treatment in the Korean epileptic patients in the clinical setting. J Biochem Mol Biol. 2007;40(3):448-52.

61. Mamiya K, Ieiri I, Shimamoto J, Yukawa E, Imai J, Ninomiya H, et al. The effects of genetic polymorphisms of CYP2C9 and CYP2C19 on phenytoin metabolism in Japanese adult patients with epilepsy: studies in stereoselective hydroxylation and population pharmacokinetics. Epilepsia. 1998;39(12):1317-23.

62. McCluggage LK, Voils SA, Bullock MR. Phenytoin toxicity due to genetic polymorphism. Neurocrit Care. 2009;10(2):222-4.

63. Ninomiya H, Mamiya K, Matsuo S, Ieiri I, Higuchi S, Tashiro N. Genetic polymorphism of the CYP2C subfamily and excessive serum phenytoin concentration with central nervous system intoxication. Ther Drug Monit. 2000;22(2):230-2.

64. Odani A, Hashimoto Y, Otsuki Y, Uwai Y, Hattori H, Furusho K, et al. Genetic polymorphism of the CYP2C subfamily and its effect on the pharmacokinetics of phenytoin in Japanese patients with epilepsy. Clin Pharmacol Ther. 1997;62(3):287-92.

65. Soga Y, Nishimura F, Ohtsuka Y, Araki H, Iwamoto Y, Naruishi $\mathrm{H}$, et al. CYP2C polymorphisms, phenytoin metabolism and gingival overgrowth in epileptic subjects. Life Sci. 2004;74(7): 827-34.

66. Brandolese R, Scordo MG, Spina E, Gusella M, Padrini R. Severe phenytoin intoxication in a subject homozygous for CYP2C $9 * 3$. Clin Pharmacol Ther. 2001;70(4):391-4.

67. Jose L, Binila C, Chandy SJ, Mathews JE, Mathews KP. Acenocoumarol and phenytoin toxicity in the presence of CYP2C9 mutation. J Assoc Physicians India. 2008;56:250-2.

68. Kidd RS, Straughn AB, Meyer MC, Blaisdell J, Goldstein JA, Dalton JT. Pharmacokinetics of chlorpheniramine, phenytoin, glipizide and nifedipine in an individual homozygous for the CYP2C9*3 allele. Pharmacogenetics. 1999;9(1):71-80.

69. Ramasamy K, Narayan SK, Chanolean S, Chandrasekaran A. Severe phenytoin toxicity in a CYP2C $9 * 3 * 3$ homozygous mutant from India. Neurol India. 2007;55(4):408-9.

70. Baumann P, Nil R, Souche A, Montaldi S, Baettig D, Lambert S, et al. A double-blind, placebo-controlled study of citalopram with and without lithium in the treatment of therapy-resistant depressive patients: a clinical, pharmacokinetic, and pharmacogenetic investigation. J Clin Psychopharmacol. 1996;16(4):307-14.

71. Herrlin K, Yasui-Furukori N, Tybring G, Widen J, Gustafsson LL, Bertilsson L. Metabolism of citalopram enantiomers in CYP2C19/CYP2D6 phenotyped panels of healthy Swedes. Br J Clin Pharmacol. 2003;56(4):415-21.

72. Peters EJ, Slager SL, Kraft JB, Jenkins GD, Reinalda MS, McGrath PJ, et al. Pharmacokinetic genes do not influence response or tolerance to citalopram in the STAR*D sample. PLoS One. 2008;3(4):e1872.

73. Rudberg I, Mohebi B, Hermann M, Refsum H, Molden E. Impact of the ultrarapid CYP2C19*17 allele on serum concentration of escitalopram in psychiatric patients. Clin Pharmacol Ther. 2008;83(2):322-7.

74. Sindrup SH, Brosen K, Hansen MG, Aaes-Jorgensen T, Overo KF, Gram LF. Pharmacokinetics of citalopram in relation to the sparteine and the mephenytoin oxidation polymorphisms. Ther Drug Monit. 1993;15(1):11-7.

75. Yin OQ, Wing YK, Cheung Y, Wang ZJ, Lam SL, Chiu HF, et al. Phenotype-genotype relationship and clinical effects of citalopram in Chinese patients. J Clin Psychopharmacol. 2006;26(4): 367-72.

76. Yu BN, Chen GL, He N, Ouyang DS, Chen XP, Liu ZQ, et al. Pharmacokinetics of citalopram in relation to genetic polymorphism of CYP2C19. Drug Metab Dispos. 2003;31(10):1255-9.

77. Rudberg I, Hendset M, Uthus LH, Molden E, Refsum H. Heterozygous mutation in CYP2C19 significantly increases the concentration/dose ratio of racemic citalopram and escitalopram (S-citalopram). Ther Drug Monit. 2006;28(1):102-5.

78. Ohlsson RS, Mwinyi J, Andersson M, Baldwin RM, Pedersen RS, $\mathrm{Sim}$ SC, et al. Kinetics of omeprazole and escitalopram in relation to the CYP2C19*17 allele in healthy subjects. Eur J Clin Pharmacol. 2008;64(12):1175-9. 